\title{
SKUTKI ROZCZAROWANIA ŚWIATEM
}

Łukasz Pawłowski

Uniwersytet Warszawski

\section{/// Bronisław Baczko. Rousseau: Samotności i wspólnota}

Osobliwe zjawisko! Jedyne wprost w naszej literaturze, a nawet sqdze, we wszystkich literaturach świata. Ten wtóczega, próżniak, samouk [...] występuje pierws zy raz jako autor majac pod çterdziestke, pisze w ciagu dziesięciu lat $i$ wśród nieustannych prawie cierpien fisycznych tray çy cztery ksiąiki, ani zbyt tegie, ani zbyt bogate w myśli, ale praynoszace z soba nony sposób czucia i jakiś dreszcz dotychczas nieznany; który później zanurza się w powolne szaleństwo - i który, dzięki tym paru ksią̇kom, mocen jest przekesztatcićpo swej śmierci literature, bistorie $i$ zmienic koryto całego życia narodu, do którego sam nie należat: cóż za niestychane wydarzenie!

Tak oto emfatycznie uzasadnia swoje zainteresowanie myśla Jana Jakuba jednocześnie nią oczarowany i rozczarowany - Jules Lemaitre ${ }^{1}$. Wyrwana z kontekstu opinia ta jest $\mathrm{w}$ równym stopniu prawdziwa, co niesprawiedliwa, podobnie jak wszelkie inne twierdzenia, które tajemnicy oddziaływania pism „obywatela Genewy” upatrują wyłącznie we wprowadzeniu przez nie „nowego sposobu czucia”, równocześnie moc tego oddziaływania zdecydowanie przeceniając. Skrajnego przykładu takiej pobieżnej oceny Rousseau dostarcza Bertrand Russell. Nie dość, że odmawia on Janowi Jakubowi tytułu filozofa, a jego znaczenie w historii myśli społecznej tłumaczy wyłącznie tym, iż „trafiał do serc i tego, co wówczas nazywano «wrażliwością»", to równocześnie obarcza go odpowiedzialnością za totalitarne zło XX wieku. „Począwszy od jego czasów ludzie uważający się za reformatorów dziela się na dwie grupy: na jego uczniów i na uczniów Locke'a. [...] Stopniowo [...] owa antynomia stawała się oczywista.

\footnotetext{
${ }^{1}$ Lemaitre, Jules, Jean Jacques Rousseau. «Première conférence», cyt za: Żeleński, Tadeusz (Rousseau 1978: 5).
} 
Dzisiaj konsekwencją myśli Rousseau jest Hitler; Roosevelt i Churchill sa pokłosiem Locke'a" (Russell 2000: 781) ${ }^{2}$. Na tle tego rodzaju prostych, by nie powiedzieć prostackich, a wciąż spotykanych interpretacji myśli Jana Jakuba, książki takie jak Bronisława Baczki Rousseau: samotność i wspólnota niestrudzenie udowadniają, że szwajcarski filozof był kimś więcej niż autorem popularnego romansu, bawidamkiem oraz samotna gwiazda XVIII-wiecznej popkultury, a jednocześnie bronia go przed zarzutem (często, jak w przypadku Russella, formułowanym przez te same osoby) inspirowania największych zbrodni w historii ludzkości. Spór o myśl Rousseau toczy się do dnia dzisiejszego, a książka Baczki dostarcza bardzo interesującej perspektywy jej interpretacji.

Istota tego punktu widzenia zawarta jest już w samym tytule. Baczko patrzy na myśl Rousseau przez pryzmat paradoksów społecznego oraz indywidualnego wymiaru ludzkiego życia. Sprzeczność ta zostaje ujęta przede wszystkim jako relacja między jednostkową wolnością a postępującym wraz z rozwojem cywilizacji uzależnieniem człowieka od „Innego” - od jego usług, wytworów pracy, ale także - a może przede wszystkim - od jego wartościującego spojrzenia. Analizy tego procesu dokonuje Rousseau głównie w obu tzw. rozprawach, czyli Rozprawie o naukach i sz̨tukach oraz Rozprawie o pochodženiu $i$ nierównościach miedzy ludźmi. Pierwotnej wolności przeciwstawione jest $\mathrm{w}$ nich zniewolenie przez drugiego człowieka, pierwotnej równości - społeczna stratyfikacja, pierwotnej zaś bezpośredniości - alienacja od prawdziwego „ja”. Sama treść tych poglądów Rousseau (w odróżnieniu od oceny ich słuszności) jest stosunkowo jasna i budzi dziś relatywnie niewielkie kontrowersje, których przytoczenie nie jest w tym miejscu konieczne. O wiele bardziej interesujące niż zdiagnozowanie stanu społeczeństwa jest bowiem w kontekście książki Baczki pytanie o receptę na wyjście z kryzysu. Czy Rousseau jej dostarcza? Bez wątpienia próbuje, ale czy jest w tej próbie konsekwentny, czy też, zniechęcony następującymi po sobie klęskami, w kolejnych pismach przyznaje się do porażki, kreśląc coraz mniej ambitne projekty zmian? Innymi słowy, czy dzieło Jana Jakuba powinniśmy postrzegać jako jedną całość, czy też należy wyróżnić w nim - jeśli nie historyczne, to wynikające z samej treści jego prac - pęknięcie, będące jednoczesnym przyznaniem się do klęski?

W ten sposób zdaje się interpretować myśl Rousseau Andrzej Waśkiewicz, kiedy zastanawia się, czy nie był on „najbardziej nieodpowiedzialnym

\footnotetext{
${ }^{2}$ Russell, Bertrand, Drieje filozofii Zachodu. Tłum. Tadeusz Banasiak, Adam Lipszyc, Michał Szczubiałka. Warszawa: Fundacja Aletheia, 2000, s. 781 [pierwsze, angielskie wydanie książki Russella ukazało się w 1945 r. - przyp. aut.].
} 
z wielkich filozofów, który zrazu wiele Człowiekowi obiecuje, a następnie - pozbawiając go złudzeń co do utopijnego charakteru swoich rad pozostawia go w końcu samemu sobie" (Waśkiewicz 2008: 368). Zdaniem autora, Rousseau w kolejnych książkach mierzy się z kluczowym dla siebie problemem alienacji $\mathrm{w}$ całkowicie odmienny sposób i niejako traci przy tym rozmach. „W przedstawionej w Umowie społeçnej republice Rousseau chce zbawić wszystkich jako obywateli, w Nowej Heloiz̨ie będzie to grupa ludzi żyjąca na pograniczu cywilizowanego świata, w Emilu zdolne do tego będą tylko odpowiednio wychowane jednostki żyjące obok zepsutego społeczeństwa, a w Wyznaniach i Marzeniach samotnego wedrowca (Rousseau 1983) ${ }^{3}$ ich autor przyznaje tę zdolność - implicite - już tylko sobie samemu" (Tamże: 315). Wyzwolenie powszechne porzuca więc Rousseau na rzecz projektów coraz bardziej arystokratycznych i zamiast do ludu, kieruje swe zalecenia do „wirtuozów” nowego modelu życia. Wirtuozeria wiąże się w tym ujęciu z postępującą obcością, wycofaniem na obrzeża społeczeństwa lub całkowicie poza nie. Powrót do autentycznego ,ja” odbywa się kosztem nawet absolutnej samotności. „Oto jestem sam na świecie, bez brata, bliźniego, przyjaciela, towarzysza poza samym sobą" - tak przecież zaczyna Rousseau swe ostatnie dzieło, Marzenia samotnego wedrowca.

Chociaż powyższa interpretacja jest interesująca i do pewnego stopnia odpowiada kolejom życia Rousseau, Bronisław Baczko patrzy na twórczość tego filozofa z innej perspektywy. U jej podstaw leży, jak już wspomniałem, dialektyczne napięcie między ,ja jednostkowym” a ,ja społecznym”, które jednak nie prowadzi do sformułowania dwóch alternatywnych sposobów jego pokonania - przez całkowite zanurzenie się we wspólnocie (Umowa społeczna) albo pełne osamotnienie (Emil, Wyznania). Baczko dostrzega w pismach Rousseau oba te zalecenia, ale przestrzega przed ich rozdzielaniem. Jedynie pozornie stanowia one niemożliwe do pogodzenia przeciwności. Zdaniem Baczki, ujęte w radykalnej formie, oba te rozwiązania zbiegają się ze sobą, ponieważ Rousseau zastępuje proste kontinuum - samotność czy wspólnota - czymś na kształt długiej i płaskiej elipsy. W tym sensie rzekomo antagonistyczne modele zachowania stają się nie tylko możliwe do pogodzenia, ale wręcz komplementarne. „Russowski model samotności - pisze Baczko - zawiera w sobie afirmację odcięcia się, odgrodzenia się jednostki od otaczającego świata. [...] Ale równocześnie

\footnotetext{
${ }^{3}$ W języku polskim dostępne są dwa wydania tej samej książki, Les Rêveries du promeneur solitaire, opatrzone jednak odmiennymi tytułami: Przechadžki samotnego marzyciela. Tłum. Maria Gniewiewska. Warszawa: Czytelnik, 1967 oraz Marzenia samotnego wedrowca. Tłum. Ewa Rzadkowska. Wrocław: Zakład Narodowy im. Ossolińskich, 1983. W niniejszym tekście posłużono się drugim z wymienionych przekładów.
} 
to pogrążenie się w immanentnym przeżyciu, gdy świadomość jednostki żywi się - jak to nazywa Jan Jakub - «swą własną substancja», jest ruchem transcendencji, przełamywania własnej izolacji. [...] Wytwarzanie zamkniętego, odgradzającego od «świata pozorów» kręgu samotności jest potępieniem istniejącego społeczeństwa - i afirmacją samowystarczalności moralnej i duchowej jednostki". Fragment ten, a zwłaszcza ostatnie twierdzenie, daje się jeszcze pogodzić z przytoczona wyżej interpretacja Andrzeja Waśkiewicza, ale dalej Baczko wyraźnie dowodzi, że owo napięcie między samotnością a wspólnotą w myśli Rousseau jest jej immanentną cechą i bynajmniej nie oznacza pęknięcia. „Właśnie w samotności, ograniczona do «samej siebie», jednostka wytwarza w marzeniach obraz «świata idealnego», przy czym granica między owym marzeniem a konstrukcja politycznych «projektów» lepszego społeczeństwa jest płynna" (Baczko 2009: 157). I chociaż Baczko przyznaje, że niezbędne do owej ucieczki w samego siebie jest „rozczarowanie światem”, Emila zaś, Nowa Heloiz̨ oraz Wyznania nazywa „powieściami o rozczarowaniu”(Tamże: 202), to Russowskiej samotności nie utożsamia jednak z „zewnątrzświatowa ascezą" Odizolowanie się nie oznacza rezygnacji z budowy lepszego społeczeństwa, ale może stanowić etap na drodze jego urzeczywistnienia. Według Baczki, wywołane rozczarowaniem „poczucie własnej obcości, zbędności i zagrożenia w świecie nierówności społecznej i alienacji scala się z marzeniem o wspólnocie społecznej, w której partycypacja w życiu i wartościach kolektywnych byłaby tożsama z ekspresja osobowości" (Tamże: 229). Zawarte w Wyznaniach oraz Marzeniach drobiazgowe studium własnej samotności może być w tym świetle potraktowane jako „instruktaż” dla tych wirtuozów Russowskiej walki z alienacją, którzy nadejda po nim. Wycofanie się w głąb własnej duszy to nie kapitulacja, lecz ostateczne dopełnienie dzieła. Zalecając ucieczkę w samotność, Rousseau nie ponosi więc klęski, ale pokrętnymi drogami prowadzi nas do świata Umony spolecznej i, co ważne, nie jest to droga jednokierunkowa. Zgodnie $z$ interpretacją Baczki, obie skrajności - pełna afirmacja własnego ,ja” oraz całkowite zatracenie się w społeczności - to dwa aspekty tego samego problemu, a nie wykluczające się alternatywy.

Andrzej Waśkiewicz pisze o Rousseau jako o myślicielu, który „zawiódł", ponieważ na początku obiecał nam fundamentalnie zmienić świat, lecz później coraz bardziej ograniczał zasięg swoich reform, na końcu tylko sobie przyznając zdolność takiej transformacji i życia zgodnie z natura. Baczko inaczej opowiada historię tej samej postaci. Dzieło Rousseau widzi jako nieustanną próbę pokonania pewnej dychotomii, którą symbolicznie 
wyraża w tytule swojej książki, i dowodzi, że każda kolejna praca jego bohatera ukazuje ową dychotomię w innym świetle, bez rezygnacji z prób jej przezwyciężenia.

Nie sposób na kilku stronach recenzji - rozszerzenie objętości tekstu niewiele by tu zreszta pomogło - odpowiedzieć na pytanie, która z tych interpretacji jest „prawdziwsza” i czy jeden z autorów nie traktuje swojego bohatera nazbyt surowo, drugi zaś nie stara się nazbyt ujednolicić myśli filozofa niejednokrotnie oskarżanego o brak systematyczności. Za brak takiej konkluzji nie należy jednak obwiniać recenzenta. Jego celem było bowiem wyłącznie pokazanie, jak prace Waśkiewicza i Baczki wchodzą ze sobą w interesującą dyskusję, która pozwala lepiej poznać i lepiej zrozumieć możliwości interpretacyjne pewnego fragmentu myśli Jana Jakuba.

Bibliografia:

/// Baczko, Bronisław. 2009. Rousseau: Samotność i wspólnota. Warszawa: słowo/obraz terytoria.

/// Rousseau, Jean Jacques. 1978. Wyznania. Warszawa: Państwowy Instytut Wydawniczy.

/// Rousseau, Jean Jacques. 1983. Marzenia samotnego wedrowca. Tłum. E. Rzadkowska. Wrocław: Zakład Narodowy im. Ossolińskich.

/// Russell, Bertrand. 2000. Drieje filozofii Zachodu. Tłum. T. Banasiak, A. Lipszyc, Michał Szczubiałka. Warszawa: Fundacja Aletheia.

/// Waśkiewicz, Andrzej. 2008. Obcy z myboru. Studium filozofii aspotecznej. Warszawa: Prószyński i S-ka. 